\title{
Experimental studies of the effect of organic deposition on the metabolism of a coastal marine bottom community
}

\author{
John R. Kelly* and Scott W. Nixon \\ Graduate School of Oceanography, University of Rhode Island, Kingston, Rhode Island 02881, USA
}

\begin{abstract}
Experimental laboratory microcosm studies using intact sediment cores of a benthic community from mid-Narragansett Bay, Rhode Island (USA) were conducted to determine the influence of the rate of supply of organic matter on benthic metabolism and nutrient remineralization. Enrichment experiments of 3 to 4 mo duration were carried out at $15^{\circ} \mathrm{C}$ using seston filtered from bay water. Replicate benthic microcosms were either 'starved', given regular (every 3 d) organic inputs, or exposed to large 'pulses' of organic matter equivalent to 3 to 5 mo of metabolic loss. With particulate starvation, sediment oxygen uptake and inorganic nitrogen release rates decreased only slowly, approximately halving in 80 to 120 d. $\mathrm{O}_{2}$ uptake, $\mathrm{CO}_{2}$ release, and $\mathrm{NH}_{4}{ }^{+}$release all increased immediately in response to a pulse input, subsequently declining exponentially towards the original levels within 1 to $2 \mathrm{mo}$. Rates increased gradually under regular organic additions and declined quickly when the inputs were discontinued. The magnitude of the increase in dissolved fluxes was a function of both the quantity deposited per unit time and the initial remineralization rate of the added organic matter. Our results offer direct evidence that organic input from the water column can exert a major influence on the magnitude (and variability) of sediment-water exchange rates. Within 2 mo, about 24 to $30 \%$ of the organic nitrogen and 11 to $20 \%$ of the organic carbon experimentally deposited to the sediment surface had returned to the overlying water as dissolved inorganic decomposition products. We calculate that, for the in situ mid-Narragansett Bay sediment community, over $80 \%$ of the annual $\mathrm{C}$ and $\mathrm{N}$ deposition may be remineralized and returned to the overlying water. We suggest that, although having demonstrated a pronounced effect of organic inputs upon benthic metabolism, we may be underestimating the effect since the initial remineralization rates of field deposition may be even more rapid than in our experiments.
\end{abstract}

\section{INTRODUCTION}

During the past decade a number of studies have shown that a significant portion of the primary productivity of many coastal marine waters is supported by remineralization of nutrients by bottom communities (Zeitzschel, 1980; Nixon, 1981). The coupling of benthic and pelagic components of shallow waters also implies that events in the water column will influence benthic metabolism. With few exceptions (Hargrave, 1980; Nixon et al., 1980; Kelly, 1983), this aspect of sediment-water interaction has received much less attention.

\footnotetext{
- Present address: Ecosystems Research Center, 237 Corson Hall, Comell University, Ithaca, New York 14853, USA
}

The situation has persisted largely because the actual input of organic matter to the benthos has been difficult to determine quantitatively or qualitatively. Estimates of sedimentation have been attempted in shallow coastal areas (review of Zeitzschel, 1980), but Steele and Baird (1972), Oviatt and Nixon (1975) and others have shown that resuspension of bottom sediments into settlement traps can contribute more to the traps than deposition of fresh 'primary' particles from the water column. A second direct approach, the measurement of surface sediment organics, is fraught with the same problem of mixing of fresh material with background sediments (by bioturbation), plus an additional problem. Although the surface sediment organic matter content can be easily measured, the measurement can only be used as an estimate of the more refractory substances remaining after some unknown 
portion of the 'primary' input has already been consumed. However, this residual store of organic matter is probably not the food supply for the benthic system (Marshall, 1972).

Given these difficulties, other methods have been used to provide insight into the problem. Benthic metabolism has been correlated with pelagic carbon production. Hargrave (1973) demonstrated that the oxygen uptake by sediment cores from a number of aquatic ecosystems could be correlated with primary production and the depth of the water column mixed layer. Nixon (1981) summarized data for a number of shallow marine coastal systems and derived a linear relation between available pelagic carbon (autochthonous and allochthonous input combined) and benthic oxygen uptake. On an annual basis, at least $25 \%$ of the available pelagic carbon seemed to be consumed by the benthic community. In extensive studies dealing with the flux of organic matter to the benthos, Hargrave (1978, 1980), Hargrave and Taguchi (1978), and Taguchi and Hargrave (1978), measured water column particles and settlement trap material, along with benthic metabolism. Curiously, the oxygen uptake of trap material (used to estimate the contribution of 'primary' input) did not generally indicate an immediate impact upon benthic metabolism. However, in no study has the actual organic input been measured. Even a short-term linkage between particulate input and metabolic response of the benthos has only been achieved indirectly, in large marine experimental microcosms (Kelly, 1983).

This paper reports the results of a microcosm experiment, using relatively undisturbed samples of a natural bottom community from Narragansett Bay, Rhode Island (USA), designed to study the effect of particulate organic deposition on the oxygen uptake and nutrient remineralization of the benthic community. An ancillary experiment investigated the rate of decomposition of particulate organic matter in sediment relative to that in seawater. We describe the temporal nature of the response of the sediment system to variations in organic supply rate. We have previously described (Nixon et al,, 1980) some results of these experiments relating to phosphorus regeneration. The fate of experimentally deposited organic carbon and nitrogen is more extensively discussed in this paper.

\section{METHODS}

\section{Benthic microcosms}

Sediment collection and laboratory conditions

Cores were collected by SCUBA diver at a wellstudied station (Nephtys-Nucula macrofaunal com- munity, $7 \mathrm{~m}$ water depth) north of Conanicut Island in mid-Narragansett Bay (Hale, 1974; Nixon et al., 1976 1980; McCaffrey et al,, 1980; Seitzinger et al,, 1980; Beach, 1981; Douglas, 1981; Elderfield et al., 1981; Garber, 1982). Divers carefully pushed cores - opaque PVC, similar to those of Aller (1977) - to a depth of 7 to $14 \mathrm{~cm}$, retrieving surface sediment and benthos with a relatively undisturbed sediment-water interface (170 $\mathrm{cm}^{2}$ ) and a 6 to $13 \mathrm{~cm}$ water column (varying with the depth of sediment retrieved). Cores were maintained in the dark in a bay water bath at the field temperature until they were returned to the laboratory and set in the dark in a temperature-controlled water bath. Each core had a top plate which was removed once in the laboratory; this facilitated the semicontinuous replacement of overlying water (varying from 1 to 2 l) with filtered seawater (in-line cartridge system ending with $0.5 \mu \mathrm{m}$ Pall Ultipore filter). Air was gently blown across the water surface of each core; coupled with about a $12 \mathrm{~h}$ water renewal time, the dissolved oxygen in the overlying water was thus kept above $75 \%$ of saturation and nutrient concentrations were similar to Narragansett Bay bottom waters.

Design of particulate input experiment

Ten cores, representing benthic conditions before the 'winter-spring phytoplankton bloom' (Pratt, 1965), were collected on December 6, 1976, at an in situ temperature of $6^{\circ} \mathrm{C}$. In the laboratory, the water bath temperature was gradually raised over $2 \mathrm{wk}$ to $15^{\circ} \mathrm{C}$, where it was held $\left( \pm 1 \mathrm{C}^{\circ}\right)$ for the rest of the experiment. Two of the cores were sacrificed to establish initial values for pore water ammonium and particulate organic carbon, nitrogen and phosphorus concentrations. There were then 2 replicates for each of 4 treatments (Fig. 1). All treatments received only filtered seawater during the first $27 \mathrm{~d}$ in the laboratory. The 'starved treatment' continued to receive only filtered seawater thereafter

The remaining 3 treatments received a particulate organic input, but differed either in the amount of material added or the length of time over which material was added (Fig. 1); treatment designations reflect these 2 variables. In the absence of good estimates of in situ deposition rates, the magnitudes of particulate organic matter (POM) input were chosen, and the treatments were designated, in reference to the measured daily inorganic $\mathrm{C}$ and $\mathrm{N}$ released by the sediments. Two types of POM delivery, either a one-time addition or repeated additions over a month-long period, were respectively designated 'pulse' or 'continuous'

One treatment, designated $(150 \times)$ pulse, was given 


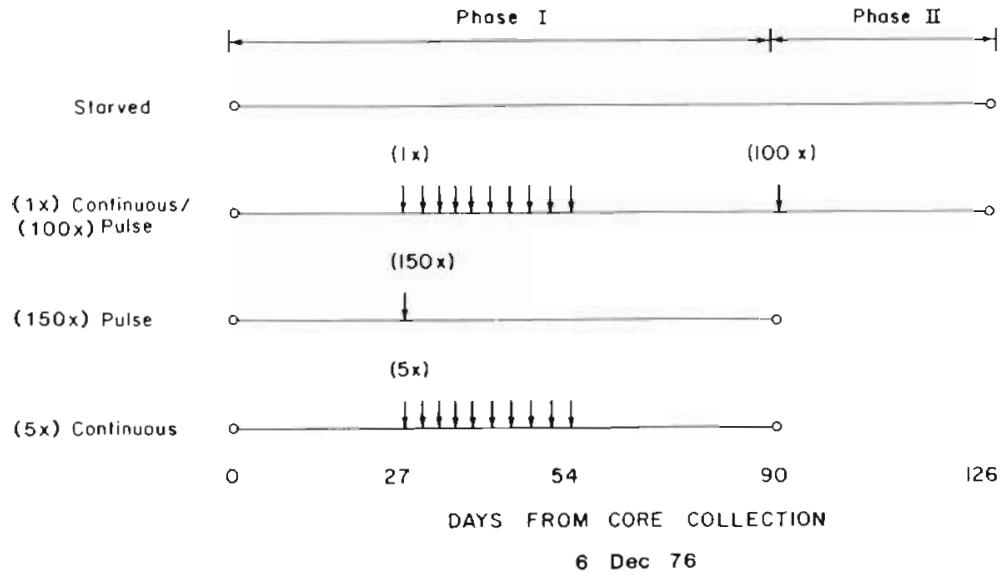

Fig 1. Design of particulate organic matter (POM) addition experiment. There were 2 replicate sediment cores for each of the 4 treatments. Arrows: addition of POM to sediment core surface. Magnitude of particulate organic carbon added expressed as a multiple of the measured daily release of dissolved inorganic carbon (i.e. $1 \times, 5 \times, 100 \times, 150 \times$; see text). Actual weight of POM addition was: $1 \times=50 \mathrm{mg}$ POM per $3-d$ installment; $5 \times=250 \mathrm{mg}$ POM per 3-d installment; $100 \times=1500 \mathrm{mg}$ POM one time addition; $150 \times=2500 \mathrm{mg}$ POM, one time addition. Composition of POM for Phases I and II is given in Table 4 on Day 27, a single addition of POM (2500 mg) representing roughly 150 times the measured daily release (prior to POM addition) of respiratory $\mathrm{CO}_{2}-\mathrm{C}$ and excretory dissolved inorganic nitrogen (DIN) to the overlying water. The large pulse was intended to mimic an input due to deposition of POM from the cessation of an intense winter-spring phytoplankton bloom characteristic of Narragansett Bay. Previously we had noted that the benthos had higher rates of nutrient release following such an event in the field (Nixon et al., 1980) and wished to describe the temporal nature of the benthic response by this experiment.

A third treatment, designated $(5 \times)$ continuous, received a regular input of POM, divided into 10 installments. The 2 cores of this treatment each received $250 \mathrm{mg}$ POM every $3 \mathrm{~d}$, thereby representing, on an average daily basis, about 5 times the background loss of $C$ and $N$ over 1 mo. Thus, the total amount of POM added to the sediment surface in the $(5 \times)$ continuous treatment (i.e. $[5 \times]$ times 30 d) was equal to the $(150 \times)$ pulse treatment. A continuous input was intended to describe the benthic response to deposition during continuous high rates of primary production, as in summer in Narragansett Bay (Furnas et al., 1976). Metabolism of the $(150 \times)$ pulse and $(5 \times)$ continuous treatments was measured only through Day 86; pore water and particulate analyses were performed several days after that (methods detailed below).

The fourth treatment had both POM delivery types, continuous followed by pulse, and the magnitude of POM input differed from the other treatments (Fig. 1). The $(1 \times)$ continuous (Phase I) input was about equal to the measured daily loss of $\mathrm{C}$ and $\mathrm{N}$, or $50 \mathrm{mg}$ POM per every $3 \mathrm{~d}$ over 1 mo (Day 27 to 54 ). A $(100 \times)$ pulse of POM (Phase II) was delivered to these same 2 cores about 5 wk (of starvation) after the last Phase I addition. Metabolism of both the starved treatment and this
$(1 \times)$ continuous $/(100 \times)$ pulse treatment was measured through Day 118; again, pore water and particulate analyses were performed shortly thereafter.

Comparison of metabolism of POM in seawater and in sediment

In Phase II of the $(1 \times)$ continuous $/(100 \times)$ pulse treatment, the same POM used as an input to the sediment cores was also added to one liter flasks of filtered (Reeve Angel Type 934AH glass fiber) seawater to attempt a comparison of remineralization in seawater versus that in sediment. (Note: throughout this paper we refer to 'remineralization' as the net release of inorganic $\mathrm{C}, \mathrm{N}$, or $\mathrm{P}$ to seawater, exclusive of sediment pore waters, from decomposing POM in seawater or in sediments.) The amount added to the sediment cores (1500 mg POM) was larger than the amount added to flasks (500 mg POM) because the two treatments had approximately equivalent inputs per unit of bottom surface area. Direct comparisons of rates of exchange were made per unit weight of added POM, after subtraction of the background sediment exchange rate prior to POM addition.

\section{Particulates used as input material}

The POM for Phase I was collected in a combination of plankton tows in Narragansett Bay and by filtration (62.5 $\mu \mathrm{m}$ net) from running seawater in the laboratory; Phase II POM was collected only by filtration of laboratory seawater. In both cases, the POM included amorphous detrital material, copepods, and phytoplankton (Coscinodiscus, Skeletonema chains). The POM was oven dried at 60 to $70^{\circ} \mathrm{C}$, mixed to homogeneity, and weighed out in the aliquots used for each addition. When added to cores (or flasks), the 
POM was rehydrated in about $20 \mathrm{ml}$ of filtered seawater for 5 to $10 \mathrm{~min}$. The POM was spread evenly over the sediment surface by 'pouring' the rehydrated slurry into the overlying core water. All water renewal and sampling was carefully conducted without disturbance of the surface flocculent layer of the sediment.

\section{Analytical methods}

\section{Flux measurements}

Net rates of sediment-water exchange of dissolved gases and nutrients (Table 1) were measured by replacing the top plate of each microcosm to isolate water and sediments from the atmosphere for about 5 to $6 \mathrm{~h}$, during which oxygen levels seldom fell below $80 \%$ of saturation. Previous core experiments with this sediment community had shown that oxygen uptake at an average of $90 \%$ of saturation would probably underestimate the rate at $100 \%$ of oxygen saturation by about $10 \%$ (Nixon et al., 1980). The flux was calculated, assuming that the rate was linear over time, as follows:

$F=\left[\frac{\left(C_{t}-C_{i}\right)}{\left(t_{f}-t_{j}\right)}-\frac{\left(C_{c}-C_{i}\right)}{\left(t_{c}-t_{i}\right)}\right] \times(10 d)$

where the subscripts $i, c, f=$ initial, control and final samples; $\mathrm{C}=$ concentration in either $\mathrm{mg}\left(\mathrm{O}_{2}\right)$ or umoles $\left(\mathrm{NH}_{4}{ }^{+}, \mathrm{NO}_{3}+\mathrm{NO}_{2} \mathrm{PO}_{4}, \mathrm{CO}_{2}\right)$ per liter; $\mathrm{t}=$ time, time in hours; $\mathrm{d}=$ depth of overlying water in $\mathrm{cm} ; 10=$ constant to convert from $\mathrm{l}^{-1}$ to $\mathrm{m}^{-2}$ (for the straight vertical core chamber wall); $F=$ flux in either $\mathrm{mg}$ or $\mu$ moles $\mathrm{m}^{-2} \mathrm{~h}^{-1}$. The water column was mixed at initial and final sampling, but not during the incubation. Changes in the seawater alone (control) were measured by incubating $300 \mathrm{ml}$ BOD bottles filled with seawater taken from the microcosms at the initial sampling; the seawater changes generally contributed less than $10 \%$ of the total concentration change.

Oxygen uptake and ammonium release were measured throughout the experiment at approximately

Table 1. Analytical methods for flux measurements

\begin{tabular}{|c|c|c|c|}
\hline $\begin{array}{l}\text { Com- } \\
\text { pound }\end{array}$ & $\begin{array}{l}\text { Methods } \\
\text { with comments }\end{array}$ & $\begin{array}{c}\text { Analytical precision } \\
\text { (average standard deviation } \\
\text { on duplicate analyses) }\end{array}$ & $\begin{array}{c}\text { - Effect of analytical precision } \\
\text { on flux calculation }\end{array}$ \\
\hline $\mathrm{O}_{2}$ & $\begin{array}{l}\text { Samples siphoned into volume- } \\
\text { calibrated ( } 60 \text { ml) BOD bottles, } \\
\text { titrated by Winkler method } \\
\text { (Strickland and Parsons, 1968) }\end{array}$ & $\pm 0.026 \mathrm{mg} \mathrm{O}_{2} \mathrm{l}^{-1}$ & $\begin{array}{l} \pm 0.8 \mathrm{mg} \mathrm{O}_{2} \mathrm{~m}^{-2} \mathrm{~h}^{-1} \\
\left( \pm 50 \text { moles } \mathrm{O} \mathrm{m}^{-2} \mathrm{~h}^{-1}\right)\end{array}$ \\
\hline $\mathrm{NH}_{4}^{+\mathrm{a}}$ & $\begin{array}{l}\text { Filtered samples fixed immedi- } \\
\text { ately with phenol (Solorzano, } \\
\text { 1969; modified for } 10 \mathrm{ml} \text { samples) }\end{array}$ & $\pm 0.050 \mu \mathrm{MNH}_{4}{ }^{+}$ & $+1.6 \mu$ moles $\mathrm{NH}_{4}^{+} \mathrm{m}^{-2} \mathrm{~h}^{-1}$ \\
\hline $\mathrm{NO}_{3}+\mathrm{NO}_{2}^{\mathrm{a}}$ & $\begin{array}{l}\text { Filtered samples }(\sim 50 \mathrm{ml} \text { ) frozen } \\
\text { in polyethylene bottles; analysis } \\
\text { on thawed samples (Technicon } \\
\text { Autoanalyzer Methods, 1972) }\end{array}$ & $\pm 0.024 \mu \mathrm{MNO} \mathrm{NO}_{3}+\mathrm{NO}_{2}$ & $\pm 0.75 \mu$ moles $\mathrm{NO}_{3}+\mathrm{NO}_{2} \mathrm{~m}^{-2} \mathrm{~h}^{-1}$ \\
\hline $\mathrm{PO}_{4}{ }^{\mathrm{a}, \mathrm{c}}$ & $\begin{array}{l}\text { Filtered samples ( } 50 \mathrm{ml} \text { ) frozen } \\
\text { in polyethylene bottles; analysis } \\
\text { on thawed samples (Strickland } \\
\text { and Parsons, 1968) }\end{array}$ & $\pm 0.01 \mu \mathrm{MPO} \mathrm{PO}_{4}$ & $\pm 0.3 \mu$ moles $\mathrm{PO}_{4} \mathrm{~m}^{-2} \mathrm{~h}^{-1}$ \\
\hline $\mathrm{CO}_{2}^{\mathrm{b}}$ & $\begin{array}{l}\text { Changes in pH measured with } \\
\text { Corning Digital } 112 \text { meter; } 200 \mathrm{ml} \\
\text { sample of incubation water } \\
\text { titrated with } \mathrm{CO}_{2} \text { saturated water } \\
\text { (method of Beyers et al., 1963) }\end{array}$ & $\begin{array}{l}\cdots \pm 0.002 \mathrm{pH} \text { units; } 95 \% \mathrm{C} . \mathrm{I} \text {. } \\
\text { on duplicate titrations to } \\
\text { determine slope of } \mathrm{pH} / \mathrm{CO}_{2} \\
\text { relation }( \pm 11.2 \% \text { ) }\end{array}$ & $\pm 96.5 \mu$ moles $\mathrm{CO}_{2} \mathrm{~m}^{-2} \mathrm{~h}^{-1}$ \\
\hline \multicolumn{4}{|c|}{$\begin{array}{l}\text { - Water overlying each core was mixed to homogeneity before drawing samples, thus there should be no sampling-induced } \\
\text { error in flux calculation. Analytical error effect assumes error for cores and controls are additive and assumes the average } \\
\text { standard deviation at both initial and final samples, a standard } 6 \mathrm{~h} \text { incubation, and an average } 9.25 \mathrm{~cm} \text { water column over } \\
\text { the sediment. Analytical precision is based on } \mathrm{n}=16 \text { or } n=22 \text { pairs from initial and final samples for } 8 \text { cores and controls } \\
\text { from a typical flux measurement } \\
\text { - Absolute } \mathrm{CO}_{2} \text { was not determined, } \mathrm{pH} \text { ranged from about } 8.0 \text { to } 7.85 \text { during typical incubation } \\
\text { a Samples for nutrients were filtered through Reeve Angel Type } 934 \mathrm{AH} \text { glass fiber and frozen immediately } \\
{ }^{\mathrm{b}} \mathrm{CO}_{2} \text { titration water was also filtered and refrigerated until analysis (within several days) } \\
{ }^{c} \mathrm{PO}_{4} \text { fluxes for starved cores and POM additions to sediment cores were reported in Nixon et al. (1980). Differences in } \\
\text { analytical error between Nixon et al. (1980) and here are due to differences in analytical precision and length of incubation }\end{array}$} \\
\hline
\end{tabular}


weekly intervals ( $\mathrm{n}=16$ and 17 , respectively). $\mathrm{CO}_{2}$ release was measured only over the first 7 sampling dates; thereafter the exchange rates of $\mathrm{NO}_{3}+\mathrm{NO}_{2}$ and $\mathrm{PO}_{4}$ were measured ( $\mathrm{n}=8$, Day 46 to 118 ). Flux rates for all compounds were generally significantly greater than the error induced by analytical precision (Table 1), but $\mathrm{CO}_{2}$ had the greatest relative analytical error. For example, using the average exchange rate measured for the two starved cores in mid-experiment (Day $46)$, the relative analytical error of the calculated flux was $\pm 16.9 \%$ for $\mathrm{CO}_{2}$, yet only $\pm 3.1 \%, 3.4 \%, 2.8 \%$, and $6.4 \%$ for $\mathrm{O}_{2}, \mathrm{NH}_{4}{ }^{+}, \mathrm{NO}_{3}+\mathrm{NO}_{2}$, and $\mathrm{PO}_{4}$, respectively.

\section{Pore water analyses}

Several subcores $\left(17.3 \mathrm{~cm}^{2} ; 4.7 \mathrm{~cm}\right.$ diameter plastic core liner) were carefully taken near the center of each sediment microcosm (2 initial, 8 experimental cores). Subcores with a disturbed surface (cracked, subducted) were not used. Water content was determined (1 subcore per microcosm) by weighing $1 \mathrm{~cm}$ sections of wet sediment, and drying at 60 to $70^{\circ} \mathrm{C}$ to constant weight. Water content was used to convert pore water concentration to amount per unit volume of wet sediment (Kelly, 1983).

Pore water ammonium concentration was also measured (a separate subcore) in $1 \mathrm{~cm}$ depth increments. Each $1 \mathrm{~cm}$ slice of wet sediment $(\sim 60$ to $70 \mathrm{~g})$ was put in acid-cleaned $(1 \mathrm{~N} \mathrm{HCl})$ polycarbonate centrifuge bottles and spun for 20 min (6000 RPM) at the experimental temperature, $15^{\circ} \mathrm{C}$. Processing was done under atmospheric conditions; there appears to be no effect of an oxidizing environment on ammonium, in contrast to phosphate (R. Beach, pers. comm., Univ. of R.I.). After centrifugation, the supernatant was filtered $(2.5 \mathrm{~cm}$ Gelman glass fiber filter in a pre-cleaned Millipore plastic filter cartridge). Samples were then diluted either $1: 10$ or $1: 20$ with deionized water and $\mathrm{NH}_{4}{ }^{+}$ determined (Solorzano, 1969; modified for a $10 \mathrm{ml}$ sample). Dilution gave concentrations in the range of 1 to $20 \mu \mathrm{M} \mathrm{NH}_{4}{ }^{+}$. The average standard deviation on duplicate samples (1:20 dilution, $n=76$ pairs) was \pm 0.0020 absorbance units (compared to \pm 0.0014 for standards) which amounted to an analytical precision of $\pm 2.3 \mu \mathrm{M} \mathrm{NH}_{4}{ }^{+}$in the reported pore water values.

\section{Particulate analyses}

Carbon, nitrogen and phosphorus content of POM and microcosm sediments (1 cm sections, separate 17.3 $\mathrm{cm}^{2}$ subcore) were measured using oven dried (60 to $70^{\circ} \mathrm{C}$ ) samples which had been ground in a Willey Mill (mesh \# 40). Particulate phosphorus was determined as described by Nixon et al. (1980), using about $25 \mathrm{mg}$ of POM and $150 \mathrm{mg}$ of sediment. The average coefficient of variation for duplicate analytical determination of phosphorus ( $g$ dry matter) ${ }^{-1}$ was less than $0.6 \%$ ( $n=30$ pairs). Carbon and nitrogen were determined on a Carlo Erba CHN analyzer (1 to $2.5 \mathrm{mg}$ sample of POM, 8 to $14 \mathrm{mg}$ sample of sediment) using acetanilide as a standard. Samples and standards were weighed on a Cahn electrobalance in pre-combusted $\left(450^{\circ} \mathrm{C}\right)$ silver sample containers. For sediments, samples were acidified $(1 \mathrm{~N} \mathrm{HCl})$ to remove carbonates and redried before analysis. The average coefficient of variation for duplicate analytical determination of $\mathrm{C}$ or $\mathrm{N}(\mathrm{g} \mathrm{d} r \mathrm{y}$ matter) ${ }^{-1}$ was: $2.4 \%$ and $6.2 \%$ for $\mathrm{C}$ in sediments ( $\mathrm{n}=$ 25 pairs) and POM ( $\mathrm{n}=2$ pairs), and $4.1 \%$ and $7.5 \%$

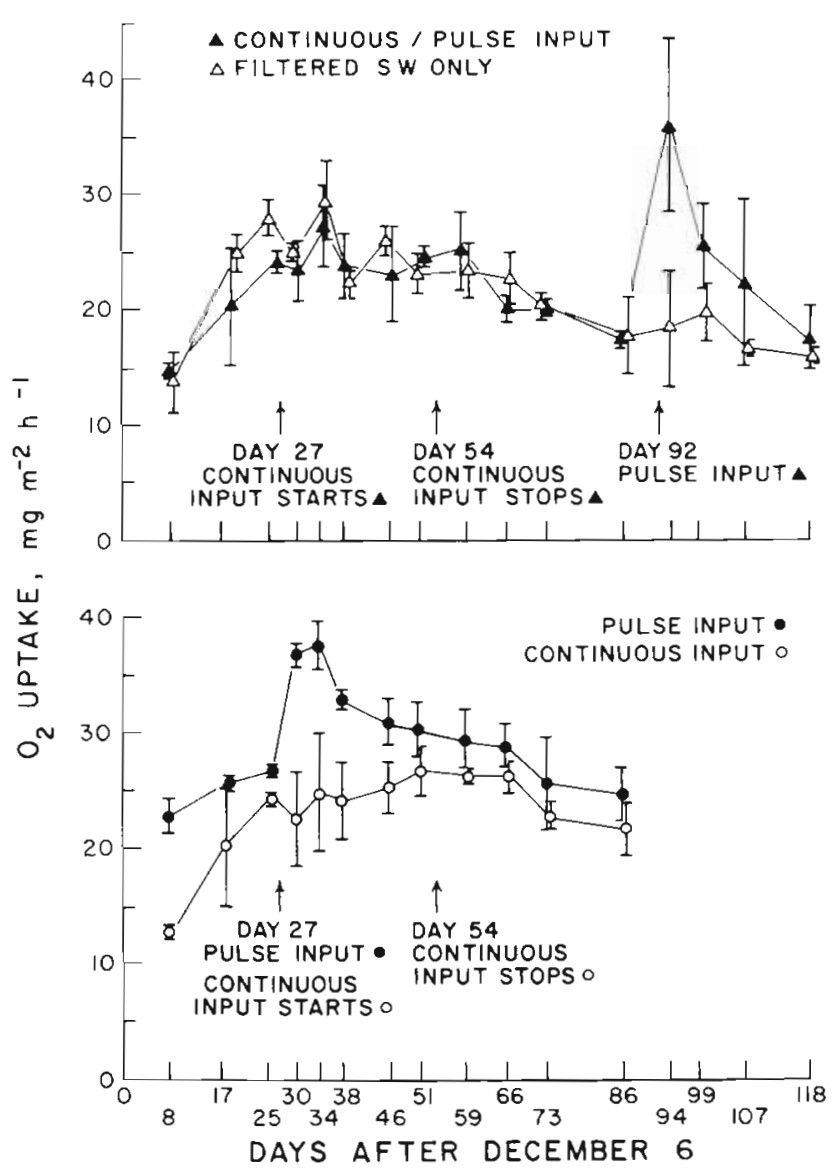

Fig. 2. Sediment oxygen uptake rates compared by treatment over time. Points and error bars: mean plus or minus 1 standard deviation of 2 replicates for each treatment at each measurement. Arrows: POM inputs start or stop for each treatment. For continuous (every $3 \mathrm{~d}$ ) inputs, some fluctuation in rate was due to the timing of a flux measurement in relation to the most recent addition. Upper graph: 'starved' treatment (filtered sw only) and $(1 \times)$ continuous $/(100 \times)$ pulse treatment. Lower graph shows $(150 \times)$ pulse and $(5 \times)$ continuous treatments 
for $N$ in sediments ( $n=25$ pairs) and POM ( $n=2$ pairs), respectively.

\section{RESULTS}

Influence of organic inputs on sediment metabolism

Sediment metabolism with no POM input

After the third week in the laboratory without any POM additions, the 8 cores had similar sediment-water exchange rates (Fig. 2 and 3), thus satisfying an experimental criterion of pre-treatment similarity. The relative variability in flux rate (Day 25) differed among compounds; the coefficient of variation was only $7.2 \%$

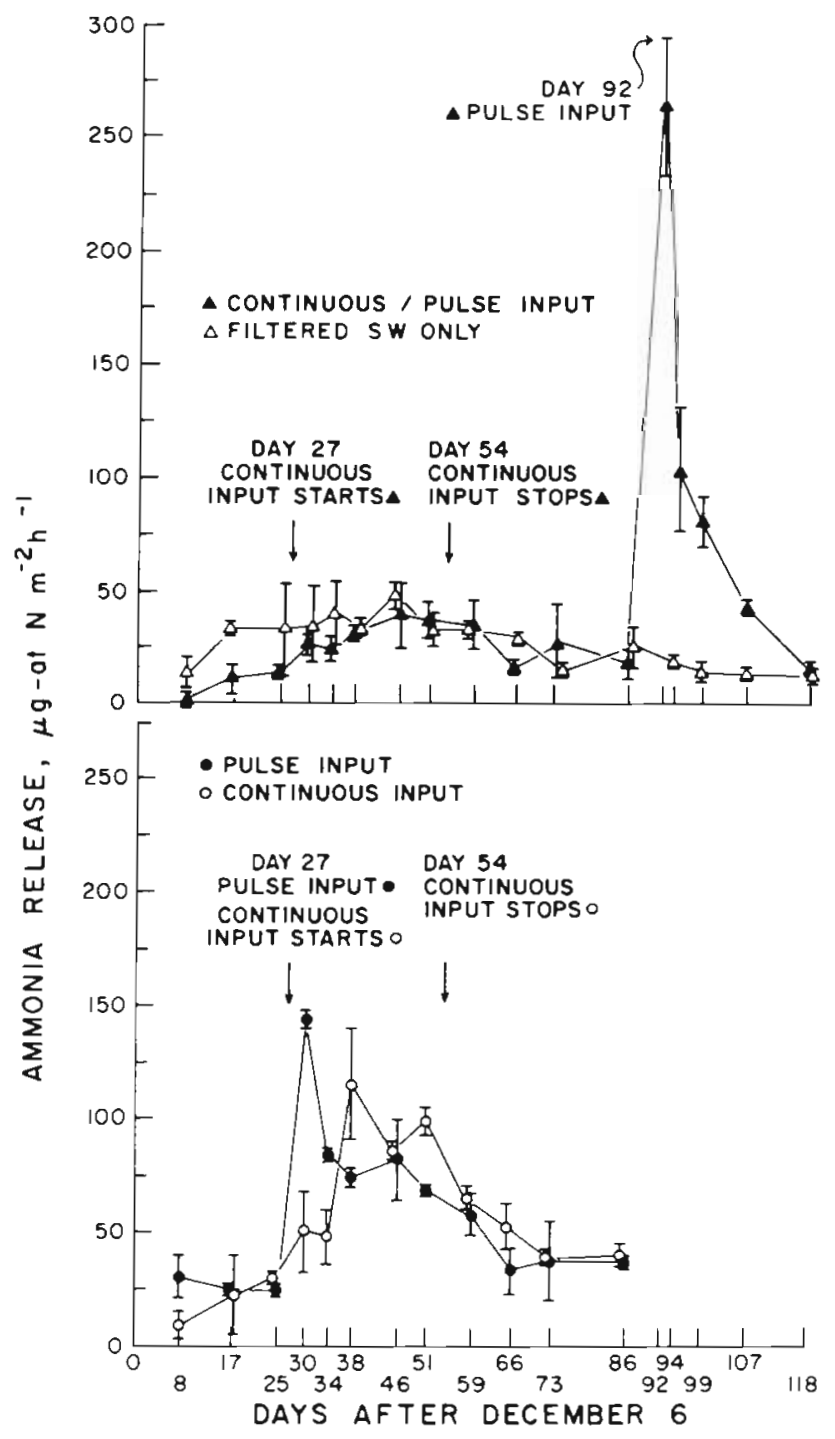

Fig. 3. Measured ammonium release rates from sediment cores compared by treatment over time. Details as in Fig. 2 for oxygen uptake and $14.0 \%$ for carbon dioxide release, yet was $46.4 \%$ for ammonium release.

Sediment-water exchange rates of the 2 cores receiving only filtered seawater after Day 25 provided an adequate control for the POM addition experiments over the next $3 \mathrm{mo}$. In response to particulate organic
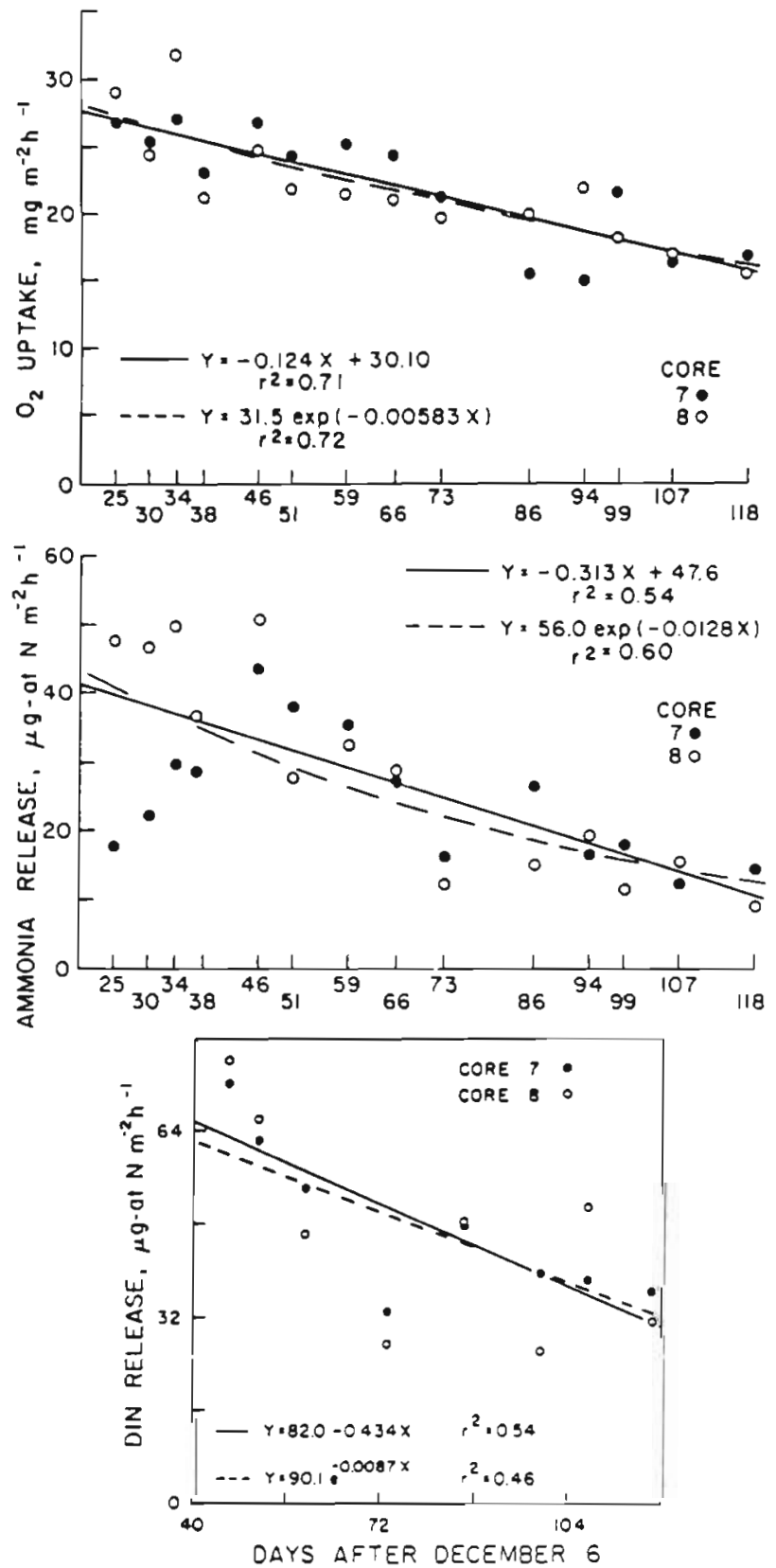

Fig. 4. Sediment-water exchange rates of oxygen, ammonium and dissolved inorganic nitrogen measured over time in two 'starved' cores. Solid line: linear regression model to predict exchange rate as a function of length of time held without particulate organic deposition. Dotted line; exponential fit to the same data. All regressions significant at $95 \%$ confidence level 
Table 2. Release of nitrate plus nitrite from sediment microcosms

\begin{tabular}{|c|c|c|c|}
\hline Treatment & $(\mathrm{N})$ & $\begin{array}{l}\text { Period } \\
\text { included }\end{array}$ & $\begin{array}{c}\mathrm{NO}_{3}+\mathrm{NO}_{2} \text { release } \\
\mu \mathrm{moles} \mathrm{Nm}^{-2} \mathrm{~h}^{-1} \\
(\overline{\mathrm{x}}+/-\mathrm{s})\end{array}$ \\
\hline$(150 \times)$ Pulse & $(10)$ & Days $46-73$ & $31.0+1-9.2$ \\
\hline$(5 \times)$ Continuous & $(10)$ & Days 46-73 & $24.7+f-11.1$ \\
\hline $\begin{array}{l}(1 \times) \text { Cont/ } \\
(100 \times) \text { pulse } \\
\text { Phase I }\end{array}$ & $(10)$ & Days $46-73$ & $26.5+-4.7$ \\
\hline Starved & $(10)$ & Days $46-73$ & $23.6+1-8.0$ \\
\hline $\begin{array}{l}(1 \times) \text { Cont } \\
(100 \times) \text { pulse } \\
\text { Phase II }\end{array}$ & (6) & Days 99-118 & $23.0+/-11.0$ \\
\hline Starved & (6) & Days 99-118 & $23.7+1-7.0$ \\
\hline
\end{tabular}

starvation, flux rates of several compounds slowly decreased. A decline in oxygen uptake was adequately described by a linear regression model indicating a halving of the uptake rate in about $121 \mathrm{~d}$ (Fig. 4). While the average ammonium release rate declined at about $1.3 \% \mathrm{~d}^{-1}$, the decrease is only evident in both replicates afer Day 40 (Fig. 4). Perhaps there were initial differences in the rate of nitrate (plus nitrite) release of these 2 cores; unfortunately the oxidized forms were not measured prior to Day 46. There was thereafter a significant nitrate (plus nitrite) release (Table 2). From Days 46 to 118 , the average nitrate (plus nitrite) release for the starved treatment was fairly constant, about 23.6 $\mu$ moles $\mathrm{N} \mathrm{m}^{2} \mathrm{~h}^{-1}$. As the $\mathrm{NH}_{4}{ }^{+}$flux decreased, the proportion of the total dissolved inorganic nitrogen (DIN) contributed by $\mathrm{NO}_{3}\left(+\mathrm{NO}_{2}\right)$ increased (Table 3$)$. Over the last 3 mo the starved core total DIN release rates thus decreased more slowly than $\mathrm{NH}_{4}{ }^{+}$alone, at about $0.9 \% \mathrm{~d}^{-1}$, halving the flux in about $80 \mathrm{~d}$. The nitrogen release rate continued to be more variable

Table 3. Composition of inorganic nitrogen release from starved cores held in the laboratory at $15^{\circ} \mathrm{C}$

\begin{tabular}{|lcccc|}
\hline Date & $\begin{array}{c}\text { Days in } \\
\text { labora- } \\
\text { tory }\end{array}$ & $\begin{array}{c}\text { \% of Inorganic nitrogen released } \\
\text { as nitrate or nitrite } \\
\text { Core } 7\end{array}$ & Core 8 & Average \\
\hline $1 / 21$ & 46 & 40 & 33 & 36.5 \\
$1 / 26$ & 51 & 38 & 58 & 48 \\
$2 / 3$ & 59 & 35 & 30 & 32.5 \\
$2 / 17$ & 73 & 52 & 55 & 53.5 \\
$3 / 2$ & 86 & 44 & 69 & 56.5 \\
$3 / 15$ & 99 & 55 & 55 & 55 \\
$3 / 23$ & 107 & 68 & 70 & 69 \\
$4 / 3$ & 118 & 59 & 71 & 65 \\
\hline
\end{tabular}

than oxygen consumption (Fig. 4). The decrease in phosphate flux (after Day 46; reported in Nixon et al., 1980) was slightly faster than either oxygen or DIN, and approached zero net flux after Day 100.

Sediment $\mathrm{CO}_{2}$ release rate, measured only through Day 46, did not decline significantly. The mean release for the first 3 wk (all 8 cores without POM, $n=24$ ) was 527 Mmoles $\mathrm{CO}_{2} \mathrm{~m}^{-2} \mathrm{~h}^{-1}$. From Days 30 to 46 , the 'starved' treatment did not differ from this value $\left(511 \pm 158 \mu\right.$ moles $\left.\mathrm{CO}_{2} \mathrm{~m}^{-2} \mathrm{~h}^{-1}, \mathrm{n}=8\right)$; a decrease probably would have been measured over a longer time.

\section{Temporal response to POM additions}

Benthic metabolism sharply increased after both large pulses of POM. Three days after the $(150 \times)$ pulse, oxygen uptake had increased from $26.6( \pm 0.6)$ to 36.6 ( \pm 1.3 ) $\mathrm{mg} \mathrm{O}_{2} \mathrm{~m}^{-2} \mathrm{~h}^{-1}$ (Fig. 2, Days 25 to 30 ). Ammonia release increased more dramatically, by a factor of 6 , to $143.8( \pm 3.2) \mu$ moles $\mathrm{NH}_{4}{ }^{+} \mathrm{m}^{-2} \mathrm{~h}^{-1}$ (Fig. 3). $\mathrm{CO}_{2}$ release increased from $539( \pm 70)$ to 1046 ( \pm 120 ) $\mu$ moles $\mathrm{CO}_{2} \mathrm{~m}^{-2} \mathrm{~h}^{-1}$ between Days 25 and 30 (the starved treatment was relatively constant, 542 $[ \pm 124]$ and $623[ \pm 79] \mu$ moles $\mathrm{CO}_{2} \mathrm{~m}^{-2} \mathrm{~h}^{-1}$ at Days 25 and 30). An immediate increase in exchange rates was also produced by the $(100 \times)$ pulse (Phase II, Day 92). At this second pulse, $\mathrm{NH}_{4}{ }^{+}$release was measured at 2 $h$ and at $20 \mathrm{~h}$ after the POM addition (cores were not sealed and air was gently blown across the surface to keep $\mathrm{O}_{2}$ levels high); $\mathrm{O}_{2}$ uptake was measured $2 \mathrm{~d}$ later. Within the first $2 \mathrm{~h}$, the ammonia release rate only increased slightly, but increased by an average of more than $240 \mu$ moles $\mathrm{N} \mathrm{m}^{-2} \mathrm{~h}^{-1}$ over the first $20 \mathrm{~h}$ (Fig. 3), indicating a short time lag between POM addition and maximum $\mathrm{NH}_{4}{ }^{+}$release. Oxygen uptake increased by an average of $18.7 \mathrm{mg} \mathrm{O}_{2} \mathrm{~m}^{-2} \mathrm{~h}^{-1}$ (Day 94, Fig. 2). The timing of the flux measurement in relation to the POM pulse, coupled with a qualitative difference in POM (Table 4, and see below), accounts for a greater initial increase in flux due to the smaller $(100 \times)$ pulse.

Following the initial pulse-induced increase, exchange rates declined exponentially over time to original levels (Fig. 2 and 3). Since a first-order decay model generally underestimated the maximum initial rate, a model of higher order may be more appropriate (Table 5). For the $(100 \times)$ pulse, rates returned to prepulse levels, which were equivalent to starved cores, within $26 \mathrm{~d}$. In contrast, sediment metabolism and nitrogen remineralization following the $(150 \times)$ pulse took slightly longer, about 5 to $6 \mathrm{wk}$, to return to original levels and, in $59 \mathrm{~d}$, never got as low as the starved treatment. 
Table 4. Composition of POM and sediments

\begin{tabular}{|c|c|c|c|}
\hline & $\begin{array}{l}\text { Carbon } \\
\text { mg C gds }\end{array}$ & $\begin{array}{l}\text { Nitrogen } \\
\mathrm{mg} \mathrm{N} \mathrm{Nds}^{-1}\end{array}$ & $\begin{array}{l}\text { Phosphonus } \\
\text { mg P gds }\end{array}$ \\
\hline \multicolumn{4}{|l|}{$\begin{array}{l}\text { Phase I POM } \\
(150 \times) \text { pulse, } \\
(1 \times) \text { and }(5 \times) \\
\text { continuous } \\
\text { treatments }\end{array}$} \\
\hline \multicolumn{4}{|l|}{$\begin{array}{l}\text { Phase II POM } \\
(100 \times) \text { pulse }\end{array}$} \\
\hline \multicolumn{4}{|c|}{$\begin{array}{l}\text { Sediment cores } \\
\text { (initial conditions, } \\
16 \text { Dec } 76 \text { ) }\end{array}$} \\
\hline$(0-1 \mathrm{~cm})$ & $15.0 \pm 0.66$ & $1.91 \pm 0.06$ & $0.625(n=1)$ \\
\hline \multicolumn{3}{|l|}{ Range } & $0.546-0.596$ \\
\hline \multicolumn{4}{|c|}{$g d s=g$ of $d r y$ sediment } \\
\hline \multicolumn{4}{|c|}{$\begin{array}{l}\text { Value represents mean } \pm \text { standard deviation of } 3 \text { determina- } \\
\text { tions for POM, } 2 \text { cores for sediments }\end{array}$} \\
\hline
\end{tabular}

Upon cessation of organic loading to the $(5 \times)$ continuous treatment, fluxes also declined (Fig. 2 and 3). Rates of exchange had gradually increased in $30 \mathrm{~d}$ of continuous enrichment and seemed to approach a new 'steady-state' rate (an increase of about $4 \mathrm{mg} \mathrm{O}_{2} \mathrm{~m}^{-2}$ $\mathrm{h}^{-1}$ and $60 \mu$ moles $\left.\mathrm{NH}_{4}{ }^{+} \mathrm{m}^{-2} \mathrm{~h}^{-1}\right)$, as a consequence of the cumulative series of successive small - i.e. $(5 \times)$ pulse-decay curves. At the end of $30 \mathrm{~d}$ the cumulative amount of POM added to the $(5 \times)$ continuous treatment equaled the single $(150 \times)$ pulse and both oxygen uptake and ammonium release were roughly comparable between these treatments. Fluxes then declined in a similar manner, without further POM, to pre-input levels. As was the general case for any decline at cessation of POM loading (including the starved treatment), the decrease in oxygen consumption was not as rapid as the decrease in $\mathrm{NH}_{4}{ }^{+}$release (Table 5, Fig. 2, 3 and 4).

Unlike the other treatments, there were no significant differences in exchange rates between the cores of

Table 5. Decline in flux after POM addition

\begin{tabular}{|c|c|c|c|c|c|c|c|}
\hline $\begin{array}{c}\text { POM } \\
\text { addition }\end{array}$ & $\begin{array}{l}\text { Com- } \\
\text { pound }\end{array}$ & $N$ & $\begin{array}{c}\text { Days (after } \\
\text { addition) of flux } \\
\text { measurements }\end{array}$ & $\mathrm{r}^{2}$ & $\begin{array}{l}\text { Model } \\
\text { type }\end{array}$ & $\begin{array}{c}\text { Model } \\
\text { parameters }\end{array}$ & $\begin{array}{l}\text { Highest } \\
\text { measured flux } \\
\text { value, day } \\
\text { before or after } \\
\text { addition }\end{array}$ \\
\hline \multirow[t]{10}{*}{$(150 \times)$ pulse } & \multirow[t]{4}{*}{ Oxygen } & 18 & $3-59$ & 0.79 & I & $F=36.8 e^{-0.00726 d}$ & \multirow{4}{*}{$\begin{array}{l}37.5,35.7 \\
\text { Day } 3\end{array}$} \\
\hline & & & & 0.70 & II & $F=45.6(d)^{-0.136}$ & \\
\hline & & 10 & $3-24$ & 0.73 & I & $F=37.8 \mathrm{e}^{-0.010 \mathrm{~d}}$ & \\
\hline & & & & 0.67 & II & $F=42.8(d)^{-0.106}$ & \\
\hline & \multirow{4}{*}{$\mathrm{NH}_{4}{ }^{+}$} & 18 & $3-59$ & 0.74 & I & $F=115 e^{-0.0235 d}$ & \multirow{4}{*}{$\begin{array}{l}146,142 \\
\text { Day } 3\end{array}$} \\
\hline & & & & 0.76 & II & $F=241(d)^{-0.4619}$ & \\
\hline & & 10 & $3-24$ & 0.52 & 1 & $F=120 e^{-0.0249 d}$ & \\
\hline & & & & 0.72 & II & $F=178(d)^{-0.306}$ & \\
\hline & \multirow[t]{2}{*}{$\mathrm{CO}_{2}$} & \multirow[t]{2}{*}{8} & \multirow[t]{2}{*}{$3-19$} & 0.29 & I & $F=920 e^{-0.0160 d}$ & 1130,963 \\
\hline & & & & 0.48 & II & $F=1107(d)^{-0.1569}$ & Day 3 \\
\hline \multirow[t]{4}{*}{$(100 \times)$ pulse } & \multirow[t]{2}{*}{ Oxygen } & \multirow[t]{2}{*}{10} & \multirow[t]{2}{*}{$2-26$} & 0.67 & I & $F=33.9 e^{-0.0276 d}$ & $30.6,41.1$ \\
\hline & & & & 0.73 & II & $F=43.0(d)^{-0.272}$ & Day 2 \\
\hline & \multirow{2}{*}{$\mathrm{NH}_{4}{ }^{+}$} & \multirow[t]{2}{*}{10} & \multirow[t]{2}{*}{$0.5-26$} & 0.91 & I & $F=176 \mathrm{e}^{-0.0955 \mathrm{~d}}$ & 281,242 \\
\hline & & & & 0.90 & II & $F=181(d)^{-0.627}$ & Day 0.5 \\
\hline \multirow[t]{4}{*}{$(5 \times)$ continuous } & \multirow[t]{2}{*}{ Oxygen } & \multirow[t]{2}{*}{8} & \multirow[t]{2}{*}{$5-32$} & 0.66 & I & $F=27.4 e^{-0.0077 d}$ & $28.1,25.1$ \\
\hline & & & & 0.60 & II & $F=32.0(d)^{-0109}$ & $\operatorname{Day}(-3)$ \\
\hline & \multirow[t]{2}{*}{$\mathrm{NH}_{4}+$} & \multirow[t]{2}{*}{8} & \multirow[t]{2}{*}{$5-32$} & 0.50 & I & $F=63.6 e^{-0.017 d}$ & $94.4,103.7$ \\
\hline & & & & 0.66 & II & $F=100.5(d)^{-0.284}$ & Day $(-3)$ \\
\hline \multicolumn{8}{|c|}{$\begin{array}{l}\text { Model } I \text { is a first-order decay model, Flux }(())=F l u x_{(0)} e^{-k(t m e)} \text {, where Flux }{ }_{(0)} \text { and } k \text { were estimated by linear regression of ln } \\
\text { (Flux) on time in days after POM addition. The value of } \mathrm{k}(\times 100) \text { estimates a } \% \text { decrease in the flux per unit time; } \mathrm{k} \text { differed } \\
\text { between compounds and between POM }(150 \times \text { pulse POM different from } 100 \times \text { pulse POM), but not between delivery } \\
\text { schedule }\left(150 \times \text { pulse similar to } 5 \times \text { continuous for both } \mathrm{O}_{2} \text { and } \mathrm{NH}_{4}^{+}\right)\end{array}$} \\
\hline \multicolumn{8}{|c|}{$\begin{array}{l}\text { Model II is a power-decay model, Flux }{ }_{(t)}=\text { Flux }_{(o)} \text { (time) }^{-k} \text {, where Flux } \\
\log (\text { Flux }) \text { and } k \text { were estimated by linear regression of } \\
\text { representation of the dynamics of detrital decomposition (Kelly, 1983) as the first-order model tends to underestimate initial } \\
\text { decay rates }\end{array}$} \\
\hline \multicolumn{8}{|c|}{ Oxygen flux in mg O $\mathrm{m}^{-2} \mathrm{~h}^{-1}, \mathrm{NH}_{4}^{+}$and $\mathrm{CO}_{2}$ flux in $\mu$ moles $\mathrm{m}^{-2} \mathrm{~h}^{-1}$} \\
\hline
\end{tabular}


the $(1 \times)$ continuous POM input and the starved cores over the $30 \mathrm{~d}$ period of addition, nor in the month following. Assuming the initial maximum exchange rates (per unit of added $\mathrm{C}$ or $\mathrm{N}$ ) were similar to the $(150 \times)$ pulse, a simple calculation confirms that the magnitude of POM added was not sufficient to analytically detect a flux increase over the background flux of a more slowly decaying, but much larger mass of organic matter within the surface sediments.

Comparison of seawater and sediment remineralization

Was the benthic metabolic response only a simple reflection of the dynamics of the added POM remineralization, with the response thereby relatively independent of the addition of the POM to the sediment surface? While our experiments only begin to address this question, clearly this was not the case with phosphorus. In comparison to POM decomposition in seawater alone, the sediments dramatically reduced the return of inorganic phosphorus to overlying waters (presented in Nixon et al., 1980). In contrast, the influence of the sediment system upon the net amount of carbon and nitrogen returned to overlying waters was far less pronounced (Table 6). The initial rate of return

Table 6. Initial remineralization of POM used in experimental deposition studies

\begin{tabular}{|c|c|c|c|}
\hline Phase & $\begin{array}{c}\% \text { returned } \\
\text { Car- } \\
\text { bon }\end{array}$ & $\begin{array}{l}\text { overlying } \\
\text { Nitro- } \\
\text { gen }\end{array}$ & $\begin{array}{l}\text { ater } \mathrm{d}^{-1} \text {. } \\
\text { Phospho- } \\
\text { rus }\end{array}$ \\
\hline \multicolumn{4}{|c|}{ Phase I POM, added to } \\
\hline sediment & $\begin{array}{l}0.5-0.8 \cdots \\
0.6-1.0 \cdots\end{array}$ & $0.9-1.35$ & - \\
\hline \multicolumn{4}{|c|}{ Phase II POM, added to } \\
\hline sediment & $1.15^{\cdots}$ & 2.8 & 13.9 \\
\hline seawater & $1.35^{\circ}$ & 3.1 & 23.6 \\
\hline \multicolumn{4}{|c|}{$\begin{array}{l}\text { Values based on release of } \mathrm{CO}_{2}, \mathrm{NH}_{4}+\text { and } \mathrm{PO}_{4} \text { to } \\
\text { overlying seawater (not including release to pore waters } \\
\text { of sediment) within the first } 2 \mathrm{~d} \text { after addition to seawater } \\
\text { or sediments. This was measured for Phase } \mathrm{II}_{;} \text {for compari- } \\
\text { son, Phase I values were backcast using Model I (lower } \\
\text { value of range) or Model II (upper value of range) of Table } \\
5 \text { since first measurement was not until Day } 3 \text {. Calculation } \\
\text { was made using increase in flux (subtracting starved core } \\
\text { flux for sediment treatment), divided by the amount of } \mathrm{C} \text {, } \\
\mathrm{N} \text { or P added in a given POM pulse } \\
\cdots \text { Values estimated from oxygen uptake, using } \mathrm{RQ}=1.0 \\
\cdots \text { Values directly determined from } \mathrm{CO}_{2} \text { release }\end{array}$} \\
\hline
\end{tabular}

of $\mathrm{C}$ and $\mathrm{N}$ from the sediment seemed only slightly reduced in comparison to seawater decomposition. The temporal decline in exchange rates between the POM and seawater was qualitatively similar to the decline in fluxes when the POM was added to the sediment (Table 5, $(100 \times)$ pulse). But the variability of the exchange rates after $1 \mathrm{wk}$, in addition to the subtraction of a large background exchange rate relative to the increased rate of sediment-water exchange, make it tenuous to try to distinguish differences between sediment and seawater POM decay over any time period other than the first few days.

\section{Fate of POM added to sediment cores}

Inputs and outputs: budgets for experimental POM additions

About $25 \%$ of the added particulate nitrogen appeared to return to the overlying water within several months as dissolved inorganic decomposition products, regardless of the magnitude of a pulse or the frequency of delivery (Table 7). The release of DIN to the overlying water due to the added POM was estimated by subtracting the slowly decreasing background release rate measured for starved cores. The release of inorganic nitrogen from the POM occurred primarily as $\mathrm{NH}_{4}{ }^{+}$, although there may have been a slight increase in the nitrate (plus nitrite) release from cores receiving pulse inputs (Table 2). $\mathrm{NO}_{3}\left(+\mathrm{NO}_{2}\right.$ ) release was included as a possible additional output (Table 7). In relation to both the total deposition of particulate organic nitrogen and the resultant release of DIN to the overlying water, the average changes in the amount of pore water ammonium between starved and experimental cores were insignificant, even if observed changes were multiplied by a factor of 2 to 3 to account for the $\mathrm{NH}_{4}{ }^{+}$released to pore waters that may have adsorbed to particles (Douglas, 1981). This result was not an artifact of the experiment as no major disturbance of the interstitial environment could be suggested even with the long period of confinement in the laboratory. Ammonium concentrations for all cores (Fig. 5) were similar to in situ estimates in mid-Narragansett Bay (McCaffrey et al., 1980; Douglas, 1981) and starved cores were not different from the initial conditions (for 0-6 cm depth, the mean change \pm standard deviation of 2 replicates was $-0.87 \pm 2.2$ mmoles $\mathrm{N} \mathrm{m}^{-2}$ ). Short-term increases in pore water ammonium can result from POM additions (Garber, 1982), yet in our experiments the DIN resulting from the decomposition of added POM appeared primarily in the overlying water.

Unlike nitrogen, carbon remineralization may have been sensitive to the frequency of organic input (Table 8). The return of inorganic carbon to overlying waters from a pulse input approached $20 \%$ of the POC input. 
Table 7. Nitrogen budgets for experimental deposition of particulate organic nitrogen to intact sediment cores

\begin{tabular}{|c|c|c|c|c|}
\hline \multicolumn{5}{|c|}{ All values expressed as mmoles $\mathrm{N} \mathrm{m}^{-2}$} \\
\hline Treatment & Input (date) & $\begin{array}{c}\text { Pore water } \\
\text { changes }\end{array}$ & 58 day output & $\begin{array}{l}\text { Percent returned } \\
\text { as DIN to water } \\
\text { (58 d) }\end{array}$ \\
\hline$(150 \times)$ pulse & 221 (3 Jan) & +1.51 & $\begin{array}{r}45.9 \text { as } \mathrm{NH}_{4}^{+} \\
9.7 \text { as } \mathrm{NO}_{3} \text { ? } \\
55.6 \text { as DIN }\end{array}$ & $25 \%$ \\
\hline$(5 \times)$ continuous & 221 (3 Jan-30 Jan) & +1.81 & $\begin{array}{l}53.5 \text { as } \mathrm{NH}_{4}{ }^{+} \\
\mathrm{ND} \text { as } \mathrm{NO}_{3}\end{array}$ & $24 \%$ \\
\hline$(1 \times)$ continuous & 44.2 (3 Jan-30 Jan) & NM & ND & \\
\hline$(100 \times)$ pulse & 157.5 (7 Mar) & +0.65 & $\begin{array}{c}39.3 \text { as } \mathrm{NH}_{4}^{+} \\
9.4 \text { as } \mathrm{NO}_{3} \text { ?? } \\
39.3-47.7 \text { as DIN }\end{array}$ & $25-30 \%$ \\
\hline \multicolumn{5}{|c|}{$N M=$ not measured $; \mathrm{ND}=$ not distinguishable from control } \\
\hline \multicolumn{5}{|c|}{$\begin{array}{l}\text { Pore water changes represent mean difference in the top } 0 \text { to } 6 \mathrm{~cm} \text { between starved cores and each particular treatment; } \\
\text { however, the average standard deviation between pairs of replicates }\left( \pm 1.39 \text { mmoles } \mathrm{N} \mathrm{m}^{-2} \text { ) was similar to mean change }\right. \\
\text { Output calculated by integrating increase (mean for } 2 \text { replicates per treatment), above starved cores, in release rates over a } \\
58 \mathrm{~d} \text { period. Although second pulse addition has been extended to } 58 \mathrm{~d} \text { by projecting the decay curve, the majority of release } \\
\text { occurred within the first several weeks }\end{array}$} \\
\hline
\end{tabular}

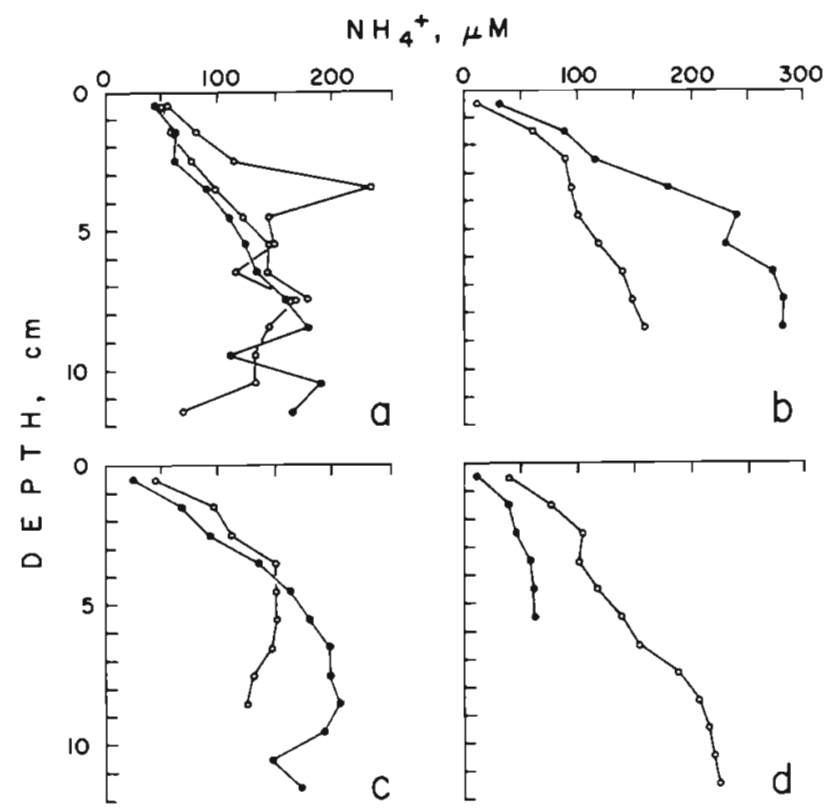

Fig. 5. Concentration of ammonium in pore waters of initial and experimental cores. (a) Initial conditions as measured by 3 subcores from 2 cores collected at same time as experimental cores, but sacrificed for chemical analyses on 16 Dec 76 . (b) $(150 \times)$ pulse addition treatment about 2 mo (6 March, 17 March 77) after POM input, subcores from each of the 2 replicates. (c) $(5 \times)$ Continuous addition treatment about $1 \mathrm{mo}$ (14 March, 19 March 77) after last addition, subcores from each of the 2 replicates. (d) Starved cores, about 4 mo after collection (20 April, 21 April 77), subcores from each of the 2 replicates

Yet, only $11 \%$ of the input returned as $\mathrm{CO}_{2}$ for the $(5 \times)$ continuous treatment over the same period as the
$(150 \times)$ pulse. The discrepancy between carbon and nitrogen outputs is puzzling. Since nitrogen was remineralized more quickly than carbon (Table 6), perhaps carbon would have been more subject to both mixing into the sediment and assimilation by the benthos.

\section{DISCUSSION}

The results from our controlled laboratory experiments using sediment microcosms offered direct evidence that the magnitude of recent organic deposition can exert a major influence on the magnitude of sediment-water exchange rates. POM input from the water column is thus experimentally confirmed as an important factor, in addition to others such as temperature (e.g. Nixon et al., 1980) and animal activity (e.g. Aller, 1977), contributing to the spatial and temporal variability of benthic fluxes observed in situ. Due to the dynamics of POM remineralization, the effects of fresh organic deposition can be fleeting, and transient increases in exchange rates may not leave a very lasting impression in the form of observable increases in either pore water nutrient concentrations or the organic content of the sediment. It required only a small amount of rapidly decomposing POM (relative to the sediment organic matter), added to the sedimentwater interface, to effect a rather dramatic change in fluxes. To further describe benthic metabolic responses to water column events we must determine how the remineralization of natural fresh deposition 
Table 8. Carbon budgets for experimental deposition of particulate organic carbon to intact sediment cores

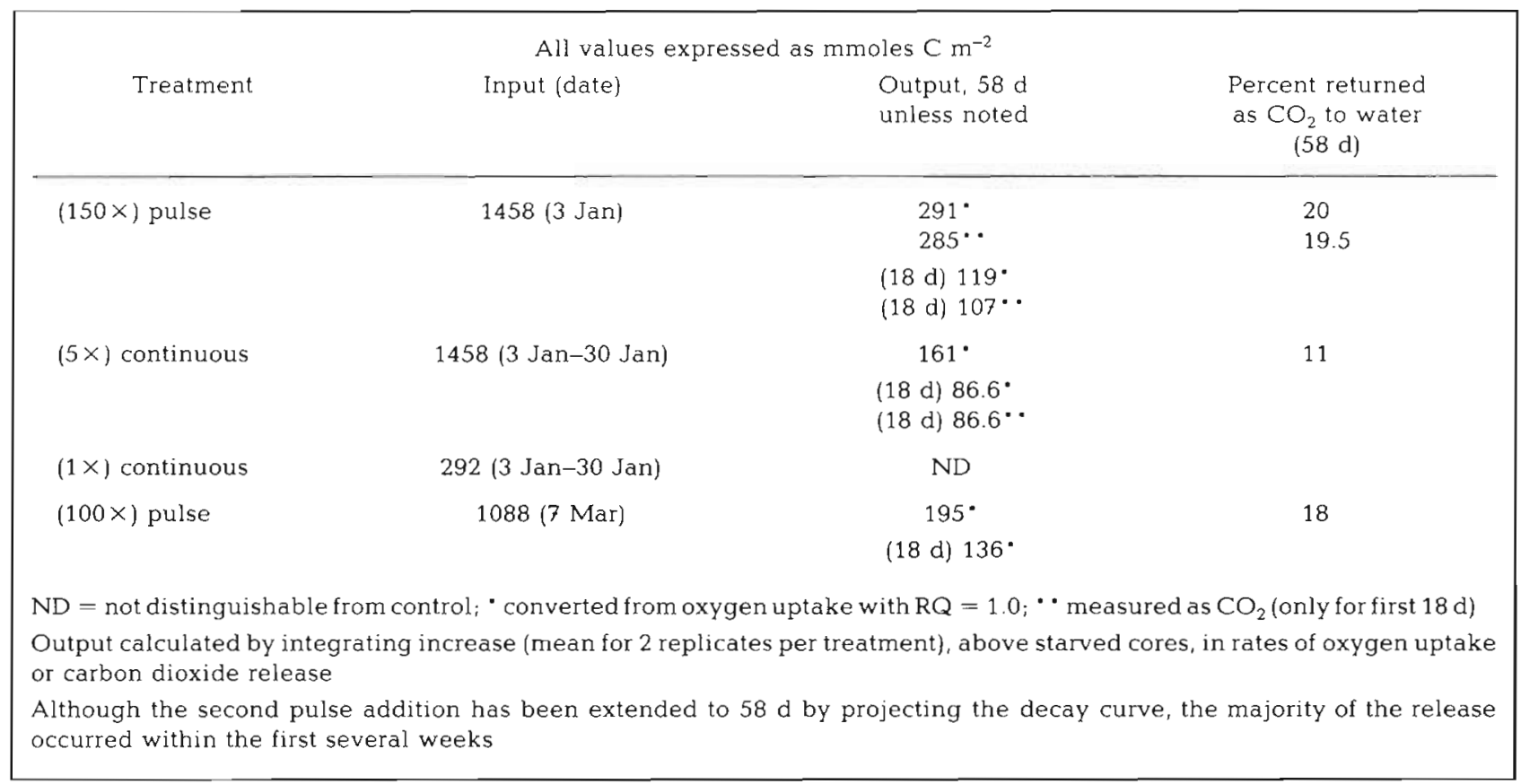

varies seasonally and whether, over longer periods, addition of POM to the sediment surface alters decomposition rates of that POM.

Unfortunately, to relate our results to the field we can at present only look at long-term averages. We constructed annual input/output budgets for mid-Narragansett Bay sediments by assuming that primary deposition was equal to the sum of outputs from the benthos plus the amount buried each year (Fig. 6). This calculation neglects year-to-year variation in benthic animal biomass and the net loss of biomass due to predation and migration. Energetic considerations require that these terms be small.

Coupling between water and sediments is a dominating feature of Narragansett Bay nutrient dynamics. The magnitude of primary deposition represents about 86 to $100 \%$ of the annual nitrogen and phosphorus loading to the Bay. However, over a year at least $92 \%$ of this primary deposition of $\mathrm{C}, \mathrm{N}$ and $\mathrm{P}$ appears to return to overlying waters, mostly as remineralized inorganic nutrients (Table 9). Less than $5 \%$ of the amount of $\mathrm{C}, \mathrm{N}$, and $\mathrm{P}$ incorporated in primary production may get buried annually.

Return of nutrients over an annual cycle in the Bay appears substantially greater than would be indicated from POM additions followed for several months in laboratory microcosms. We do not attribute this difference to the quantities of deposition involved, as the average deposition in Narragansett Bay appears to be within the range of our experimental rates of addition (Table 10). In addition, experimentally varying the
Table 9. Inputs and outputs of $\mathrm{C}, \mathrm{N}$ and $\mathrm{P}$ from mid-Narragansett Bay sediments

\begin{tabular}{|c|c|c|c|}
\hline Deposits & $\mathrm{C}$ & $\mathrm{N}$ & $P$ \\
\hline $\begin{array}{l}\text { Primary deposition as } \% \\
\text { of primary production }\end{array}$ & $51 \%+$ & $44 \%$ & $77 \%$ \\
\hline \multicolumn{4}{|c|}{$\begin{array}{l}\% \text { of primary deposits which } \\
\text { are returned to overlying } \\
\text { waters } . .\end{array}$} \\
\hline Total & $92 \%+$ & $93 \%$ & $92 \%$ \\
\hline Inorganic nutrients & $86 \%+$ & $\begin{array}{l}50 \% \\
83 \%\end{array}$ & $63 \%$ \\
\hline \multicolumn{4}{|c|}{$\begin{array}{l}\text { + Percentage could change if there is appreciable } \\
\text { release of dissolved organic carbon by sediments } \\
\text { - Includes loss as } \mathrm{N}_{2} \text { gas } \\
\text { - Phytoplankton primary production from Furnas et al. } \\
\text { (1976) assumes } \mathrm{C}: \mathrm{N} \text { : P ratio of } 106: 16: 1 \text { for uptake } \\
\cdots \text { Values calculated assuming the 'maximum' } 1.5 \mathrm{~mm} \\
\mathrm{y}^{-1} \text { penmanent burial (Fig. } 6 \text { ) and are thus 'minimum' } \\
\text { estimates }\end{array}$} \\
\hline
\end{tabular}

quantities of inputs did not seem to alter the amount returned (Tables 7 and 8 ). However, there may be periods of time in the Bay when, as with starved cores, deposition is exceeded by outputs from the sediments and the benthos consumes older material. Over long periods a larger return of the deposited organics could thus be attained and this may be a contributing factor to the difference in the percentage return to the overlying water column. 
Table 10. Nitrogen deposition in Narragansett Bay and laboratory sediment microcosms

\begin{tabular}{|lll|}
\hline \multicolumn{1}{|c}{ PON Source } & $\begin{array}{c}\text { Deposition } \\
\text { mmoles } \mathrm{N} \mathrm{m}^{-1} \\
\mathrm{~d}^{-1}\end{array}$ & \multicolumn{1}{c|}{$\begin{array}{l}\text { Time frame } \\
\text { considered }\end{array}$} \\
\hline $\begin{array}{l}\text { Field, PON primary deposition } \\
\text { mid-Narragansett Bay }\end{array}$ & 4.7 & Annual average \\
$\begin{array}{l}\text { Laboratory PON input } \\
(5 \times) \text { Continuous } \\
\text { and }(150 \times) \text { pulse } \\
(1 \times) \text { Continuous }\end{array}$ & 7.4 & $\begin{array}{l}\text { Average over } 30 \mathrm{~d} \\
\text { input period } \\
\text { Average over } 30 \mathrm{~d}\end{array}$ \\
$\begin{array}{l}(1 \times) \text { Continuous } \\
(100 \times) \text { pulse }\end{array}$ & 1.5 & $\begin{array}{l}\text { Average over } 126 \mathrm{~d} \\
\text { period in } \\
\text { laboratory }\end{array}$ \\
\hline
\end{tabular}
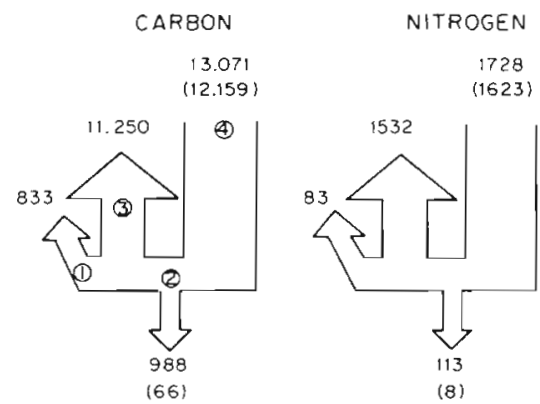

PHOSPHORUS 28 66) 189
$(175)$

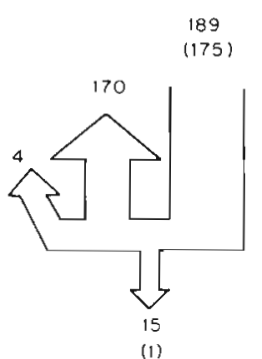

(1)

ALL IN mmoles $\mathrm{m}^{-2} \mathrm{y}^{-1}$

Fig. 6. Annual inputs and outputs of carbon, nitrogen, and phosphorus to mid-Narragansett Bay sediments. Values (mmoles $\mathrm{m}^{-2} \mathrm{y}^{-1}$ ) include all measured or estimated forms for each element. (1) Macrofaunal production available to predators; assumes $\mathrm{C} / \mathrm{N}=10$ and $\mathrm{N} / \mathrm{P}=20$ for macrofaunal tissue, and no natural mortality (Kelly, 1983). (2) 'Permanent' burial; assumes sedimentation rates of Santschi (1980), $1.5 \mathrm{~mm} y^{-1}$, or parenthetically, of Santschi et al. (1980), $0.1 \mathrm{~mm} \mathrm{y}^{-1}$; assumes buried sediment has $\mathrm{C}, \mathrm{N}, \mathrm{P}$ content similar to Table 4. (3) Dissolved flux measurements; $C$ from Nixon et al. (1976), includes no dissolved organic carbon; $N$ $=$ summation of $\mathrm{NH}_{4}+\mathrm{DON}+\mathrm{N}_{2}(870+87+575)$ from measurements of Nixon et al. (1976), Nixon (1980), and Seitzinger (1982); $\mathrm{P}=$ summation of $\mathrm{PO}_{4}+\mathrm{DOP}(120+50)$ from Nixon et al. (1980). (4) Particulate inputs to benthos, estimated by summation of outputs, (1) and (3), and amount retained in benthic system (2)

It is also likely that much of the organic input to the benthos in the field has seen relatively little previous decomposition in the water column. The 'age' of planktonic detritus at deposition determines the maximum rate at which remineralization will proceed. Therefore, the amount of time required to deposit material from the water column may also determine the percentage of nutrient returned from primary deposits. The temporal dynamics of POM decay in our experiments were very similar to that reported for other detrital

remineralization (Antia et al., 1963; Grill and Richards, 1964; Garber, 1982). However, the remineralization rates of the POM used in our experimental additions (excepting phosphorus) were probably much lower than fresh deposition. We make this suggestion on the basis of a comparison with only 2 other studies which have attempted to characterize the decomposition rate of freshly deposited material. Deposition of POM after a summer phytoplankton bloom in a MERL mesocosm (Kelly, 1983) had initial remineralization rates at $24{ }^{\circ} \mathrm{C}$ of $10.5 \%, 7.2 \%, 3.1 \%(\mathrm{~d})^{-1}$ for $\mathrm{C}, \mathrm{N}$, and $\mathrm{P}$ (compare Table 6). Additionally, we calculated from the annual average rate of oxidation of the sediment trap POM collected by Hargrave (1978) a carbon remineralization rate ('biological oxidation only', assuming $R Q=0.85$ to 1.0 ) of 5 to $5.8 \% \mathrm{~d}^{-1}$ at $10^{\circ} \mathrm{C}$. Therefore, we suggest that the deposition of autochthonous particles must be very quick, and the resultant release of nitrogen and carbon from fresh deposits in nature may be more rapid, for equivalent amounts of input, than described in our experiments.

Acknowledgements. We thank Candace Oviatt and Michael Pilson for commenting on earlier drafts of the paper. Betty Buckley, Beth Evans and Sharon Northby assisted with the laboratory analyses. Funding was provided by the office of Research and Development, U.S. Environmental Protection Agency.

\section{LITERATURE CITED}

Aller, R. C. (1977). The influence of macrobenthos on chemical diagenesis of marine sediments. Ph. D. thesis, Yale University, New Haven, Connecticut

Antia, M. J., McAllister, C. D., Parsons, T. R., Stephens, K., Strickland, J. D. H. (1963). Further measurements of primary production using a large-volume plastic sphere. Limnol. Oceanogr. 8: 166-183

Beach, R. B. (1981). Phosphorus uptake and release by sediments from Narragansett Bay. M. Sc. thesis, University of Rhode Island

Beyers, R. J., Latimer, J. L., Odum, H. T., Parker, R. B., Armstrong, N. E. (1963). Directions for the determination of changes in carbon dioxide concentrations from changes in pH. Publs Inst. mar. Sci. Univ. Tex, 9: 454-489

Douglas, G. S. (1981). The distribution of dissolved and adsorbed ammonia in Narragansett Bay sediments. M. Sc. thesis, University of Rhode Island

Elderfield, H., Luedtke, N., McCaffrey, R. J., Bender, M. (1981). Benthic flux studies in Narragansett Bay. Am. J. Sci. (281): 768-787

Furnas, M. J., Hitchcock, G. L., Smayda, T. J. (1976). Nutrientphytoplankton relationships in Narragansett Bay during the 1974 summer bloom. In: Wiley, M. (ed.) Estuarine processes, Vol. 1, Uses, stresses and adaptation to the estuary. Academic Press, New York, p. 118-134

Garber, J. H. (1982). Remineralization of nitrogen in Narragansett Bay sediments and waters. Ph. D. thesis, University of Rhode Island

Grill, E. V., Richards, F. A. (1964). Nutrient regeneration from phytoplankton decomposing in seawater. J. mar. Res. 22 $51-69$ 
Hale, S. S. (1974). The role of benthic communities in the nutrient cycles of Narragansett Bay. M. Sc. thesis, University of Rhode Island, Kingston

Hargrave, B. T (1973). Coupling carbon flow through some pelagic and benthic communities. J. Fish. Res. Bd Can. 30: $1317-1326$

Hargrave, B. T (1978). Seasonal changes in oxygen uptake by settled particulate matter and sediments in a marine bay. J. Fish. Res. Bd Can. 35: 1621-1628

Hargrave, B. T (1980). Factors affecting the flux of organic matter to sediments in a marine bay. In: Tenore, $K$. R., Coull, B. C. (ed.) Marine benthic dynamics. University of South Carolina Press, Columbia, p. 243-263

Hargrave, B. T., Taguchi, S. (1978). Origin of deposited material sedimented in a marine bay. J. Fish. Res. Bd Can. 35 $1604-1613$

Kelly, J. R. (1983). Benthic-pelagic coupling in Narragansett Bay. Ph. D. thesis, University of Rhode Island

McCaffrey, R. J., Meyers, A. C., Dowey, E., Morrison, G. Bender, M., Luedtke, N., Cullen, D., Froelich, P., Klinkhammer, G. (1980). The relation between pore water chemistry and benthic fluxes of nutrients and manganese in Narragansett Bay, Rhode Island. Limnol. Oceanogr. 25 (1): $31-44$

Marshall, N. (1972). Interstitial community and sediments of shoal benthic environments. In: Nelson, B. W. (ed.) Environmental framework of coastal plain estuaries. Geological Society of America Memphis, p. 409-415

Nixon, S. W. (1981). Remineralization and nutrient recycling in coastal marine ecosystems. In: Nelson, B., Cronin, L. E. (ed.) Nutrient enrichment in estuaries. Humana Press, New Jersey, p. 111-138

Nixon, S. W., Oviatt, C. A., Hale, S. S. (1976). Nitrogen regeneration and the metabolism of coastal marine bottom communities. In: Anderson, J. M., Macfadyen, A. (ed.) The role of terrestrial and aquatic organisms in decomposition processes. Blackwell Scientific Publishers, London, p $269-283$

Nixon, S. W., Kelly, J. R., Furnas, B. N., Oviatt, C. A., Hale, S S. (1980). Phosphorus regeneration and the metabolism of coastal marine bottom communities. In: Tenore, K. R. Coull, B. C. (ed.) Marine benthic dynamics. University of South Carolina Press, Columbia, p. 219-242

Oviatt, C. A., Nixon, S. W. (1975). Sediment resuspension and deposition in Narragansett Bay. Estuar. coast. mar. Sci. 3: 201-217

Pratt, D. M. (1965). The winter-spring flowering in Narragansett Bay. Limnol. Oceanogr. 40: 173-184

Santschi, P. H. (1980). A revised estimate for trace metal fluxes to Narragansett Bay; a comment. Estuar. coast. mar Sci. 11: 115-118

Santschi, P., Li, Y.-H., Broecker, W., Adler, D., Amdurer, M. Bell, J., Carson, S., Hinga, K., Chervin, M., Bopp, R. (1980) Trace metal cycling and interactions between sedimentwater-air phases in marine microcosms. In: Marine Ecosystems Research Laboratory Annual Report (EPA Grant \#806072020), The fate and effects of chronic low level pollutants in marine ecosystems, p. 407-574

Seitzinger, S., Nixon, S., Pilson, M. E. Q., Burke, S. (1980) Denitrification and $\mathrm{N}_{2} \mathrm{O}$ production in near-shore marine sediments. Geochim. cosmochim. Acta 44: 1853-1860

Solorzano, L. (1969). Determination of ammonia in natural waters by the phenolhypochlorite method. Limnol. Oceanogr. 14: 799-801

Steele, J. H., Baird, I. E. (1972). Sedimentation of organic matter in a Scottish sea loch. Memorie Ist. ital. Idrobiol. 29 (Suppl.): 73-88

Strickland, J. D. H., Parsons, T. R. (1968). A practical handbook of seawater analysis. Fish. Res. Bd Can. Bull. 167 $1-311$

Taguchi, S., Hargrave, B. T. (1978). Loss rates of suspended material sedimented in a marine bay. J. Fish. Res. Bd Can. 35: $1614-1620$

Technicon Autoanalyzer Methods (1972). Industrial methods for technicon autoanalyzer. Nitrate and nitrite in water and seawater. Method \# 158-71W

Zeitzschel, B. F. (1980). Sediment-water interactions in nutrient dynamics. In: Tenore, K. R., Coull, B. C. (ed.) Marine benthic dynamics. University South Carolina Press, Columbia, p. $195-212$

This paper was presented by Professor J. G. Field; it was accepted for printing on February 23, 1984 